Розділ І. Ціннісні орієнтири духовно-інтелектуального виховання, розвиток духовно-інтелектуальних якостей особистості в умовах співпраці й інклюзії

\title{
РОЛЬ ТАНЦЮ У ВИХОВАННІ ДІТЕЙ МОЛОДШОГО ВІКУ
}

\begin{abstract}
Чжан Гомінь
здобувач третього (освітньо-наукового) рівня вищої освіти кафедри освітології та інноваційної педагогіки, Харківський національний педагогічний університет імені Г. С. Сковороди, м.Харків, Україна
\end{abstract}

У статті розглядаються особливості хореографічної освіти дітей молодшого віку, до яких включаються фізичне, розумове, моральне, естетичне виховання. Виходячи з того, щяо дисиипліни художньо-естетичного циклу посідають занадто скромне місце в загальноосвітніх навчальних закладах Украӥни,необхідно розвивати систему позаурочного та позашкільного навчання.

Ключові слова: хореографія, виховання,діти молодшого віку.

The article considers the features of Children's choreographic education younger age, which includes physical, mental, moral, aesthetic education. Based on the fact that the disciplines of the artistic and aesthetic cycle occupy too modest a place in secondary schools Ukraine, it is necessary to develop a system of many extracurricular activities teaching.

Key words: choreography, education, children.

Танець - один з найдавніших видів мистецтва, він є вираженням людських почуттів, засобом духовного освоєння дійсності та пізнання прекрасного. У сучасному хореографічному мистецтві виділяють національну, класичну, бальну та дитячу хореографію.

В сучасній науково-педагогічній літературі хореографія розглядається як один $з$ допоміжних засобів фізичного, розумового, морального виховання дітей молодшого віку.

Хореографія - одне з найулюблених мистецтв дітей, бо поєднує не лише танцювальне, а й музичне, театральне та образотворче мистецтво.

У дітей молодшого віку відбуваються інтенсивні перетворення їх фізіологічних і психічних властивостей.

Виходячи 3 того, що хореографічна діяльність є синтезом фізичного та естетичного розвитку, батьки віддають дітей у хореографічні колективи.

Систематичні заняття хореографією дуже корисні для фізичного розвитку дітей. Вони поліпшують поставу, зміцнюють м’язи, усувають 
низку фізичних недоліків; сприяють рухливості суглобів, еластичності зв'язок, кардіо-респіраторній витривалості, розвитку координації рухів (нервовій, м'язовій, руховій та музично-ритмічній) і вестибулярного апарату, прискоренню процесів травлення, можливості позбутися зайвої ваги.

Заняття танцями також сприяють формуванню дисципліни, відкритості, правил поведінки в соціальних групах ( вміння відстоювати свою позицію і поважати думку інших), поняття міжособистісних відносин, почуття дружби, взаємодопомоги, лідерських якостей, впевненості у власних силах. природності і допустимої розкутості у спілкуванні з протилежною статтю, вмінню чітко розподіляти свій вільний час, привчання до акуратності, зібраності, підтягнутості.

Хореографія розкриває широкі можливості для розвитку творчого потенціалу дітей. У процесі занять хореографією у дітей формується художній смак, розвиток фантазії і здатність до імпровізації, навички самостійного творчого підходу до створення художнього образу [4].

Хореографічну освіту в Україні сьогодні діти можуть здобути переважно в позашкільних закладах, у приватних гуртках і колективах, окремих хореографічних школах. I тільки класичному танцю можна навчатися в хореографічних училищах після завершення початкової школи. Не можна не погодитися з твердженням, що дисципліни художньо-естетичного циклу посідають занадто скромне місце в загальноосвітніх навчальних закладах України. Шкільна освіта у відриві від усієї системи позаурочної та позашкільної виховної роботи об'єктивно не може реалізувати необхідний комплекс культуро-творчих функцій, притаманних мистецтву. Тому сучасні позашкільні навчальні заклади в Україні мають стати осередками виховання справжньої духовності, плекання творчої особистості, виховання людини, що характеризується високою емоційно-естетичною культурою .

На сьогодні в Україні існує Типова навчальна програма з навчальної дисципліни «Танець» елементарного підрівня початкової мистецької освіти, що може бути використана іншими суб'єктами освітньої діяльності, які реалізують програми позашкільної освіти за мистецьким напрямком. В програмі підкреслено, що важливим компонентом хореографічного мистецтва є музичний супровід, який повинен відповідати змісту навчальних завдань. Тому обов'язковою умовою є наявність у залі музичного інструмента (фортепіано, баян тощо) або медіа-про- 
Розділ І. Ціннісні орієнтири духовно-інтелектуального виховання, розвиток духовно-інтелектуальних якостей особистості в умовах співпраці й інклюзії

гравача для аудіо-записів. Музичне оформлення занять необхідно добирати з урахуванням вікових особливостей дітей [7].

На впровадженні уроків хореографії в закладах загальної середньої освіти наполягає Б. Колногузенко, адже уроки ритміки мають «незрозумілий зміст», а уроки саме хореографії сприяють духовному і фізичному вихованню дітей. До того ж уроки фізкультури також можна замінити уроками хореографії, оскільки нема у фізкультури таких завдань, які б не могла розв'язати хореографія, однак у хореографії $є$ такі завдання, які не можна розв'язати на уроках фізкультури [3].

Хореографічній освіті дітей приділяється особлива увага у багатьох країнах світу, але, звичайно, у кожній системі освіти є свої особливості. Наприклад, у КНР знайомство дітей з танцювальною творчістю починається у середній школі. У деяких закладах існують спеціальні хореографічні класи (класи 3 поглибленим вивченням народного танцю), i, як правило, діти вступають до хореографічного класу у віці десяти років. Програма спеціалізованих хореографічних класів спрямована на засвоєння танцювальних технік, що вивчаються протягом шести років. [5]. Отже, хореографічні класи при середніх школах КНР прирівнюються до хореографічних училищ. Випускники цих училищ вважаються повноцінними артистами і можуть продовжувати кар'єру без вступу до ЗВО. С також програми для молодшої школи (проєкт «Висока участь»), які розроблялися Пекінською академією танцю і були спрямовані на те, щоб зробити хореографічну підготовку загальною, а значить, вирішити питання як з талантами, так і $з$ протиріччями в хореографічній системі освіти. [5].

Розглядаючи хореографічну освіту в Україні, підкреслимо перевагу роботи позашкільних танцювальних дитячих колективів перед роботою спеціальних груп та класів класичної хореографії . Вона полягає у тому, що у перші приймаються всі бажаючі діти, не існує спецвідбору у три тури, як у спеціальні групи класичної хореографії [1].

Останнім часом в Україні збільшилась кількість дитячих танцювальних груп і студій. Наймолодші групи формуються 3 дітей від 2 років за різними напрямками: сучасним-стилізованим, бальним, класичним, народними. Формуються групи не більше 8 осіб, щоб забезпечити індивідуальний підхід до дитини. Заняття триває 30-40 хв. залежно від віку дітей [6]. 
В дитячому віці хореографія повною мірою сприяє всебічному гармонійному та фізичному розвитку дитини. Отже, хореографічна діяльність містить у собі значні можливості для всебічного гармонійного розвитку особистості дитини [2].

\section{Список використаних джерел:}

1. Васильєва T.I. Критерії початкового відбору дітей молодшого віку. http:// bo0k.net/index.php?p=achapter\&bid=16094\& chapter $=1$

2. Вацеба М.I. Вплив хореографічного мистецтва на всебічний та гармонійний розвиток учнів початкових класів. — https://naukam.triada.in.ua/index. $\mathrm{php} /$ konferentsiji/56-dvadtsyat-shosta-vseukrajinska

3. Колногузенко Б.М. Хореографічне мистецтво. Методичні матеріали для підготовки бакалаврів і спеціалістів за фахом «хореографів». (6.020200) : 3б. статей. Харків: ХДАК, 2008. 224c.

4. Кречетова П.Г. Естетичне виховання дітей молодшого шкільного віку засобами народної хореографії. — https://pandia.ru/text/79/495/53598.php

5. Максименко А.І. Хореографічна освіта в Китаї. Актуальні питання мистецької освіти та виховання. 2014. № 1-2 (3-4). С.105-113.

6. https://maisternia-znan.ua/tantsi-ta-diti-govorimo-pro-korist/

7. Типова навчальна програма з навчальної дисципліни «Танець» елементарного підрівня початкової мистецької освіти. Київ, 2019. 21 с. 